\title{
Pengaruh Model Project Based Learning terhadap Kemampuan Pemecahan Masalah Geografi
}

\author{
Raditya Ardani Hindriyanto ${ }^{1}$, Sugeng Utaya ${ }^{1}$, Dwiyono Hari Utomo ${ }^{1}$ \\ ${ }^{1}$ Pendidikan Geografi-Universitas Negeri Malang
}

\section{INFO ARTIKEL}

\section{Riwayat Artikel:}

Diterima: 22-04-2019

Disetujui: 21-08-2019

Kata kunci:
project based learning;
problem solving skill;
geography;
project based learning;
kemampuan pemecahan masalah;
geografi

\section{Kata kunci:}

geography;

kemampuan pemecahan masalah geografi

\author{
Alamat Korespondensi: \\ Raditya Ardani Hindriyanto \\ Pendidikan Geografi \\ Universitas Negeri Malang \\ Jalan Semarang 5 Malang \\ E-mail: radityahindriyanto@gmail.com
}

\begin{abstract}
ABSTRAK
Abstract: This study aims to determine the differences in geography problem solving abilities of students who learn using the PjBL model and students who learn to use conventional models. This research was a quasi-experimental (quasi experimental). The design of this study used a non-equivalent control group design. Data analysis in this study used one way anova with the help of SPSS 24.0. The results of this study indicate that the F-count value is 35,746 and $\mathrm{P}$-value $(0,000<0.05)$, which means that there are significant differences in geographic problem solving ability between the control class and the experimental class. Scores of problem solving students who use the project based learning model are better than the problem solving scores of students who use conventional models. This is because the syntax in the $\mathrm{PjBl}$ model supports problem solving activities in Geography learning.
\end{abstract}

\begin{abstract}
Abstrak: Penelitian ini bertujuan untuk mengetahui perbedaan kemampuan pemecahan masalah geografi siswa yang belajar menggunakan model PjBL dan siswa yang belajar menggunakan model konvensional. Penelitian ini merupakan eksperimen semu (quasi experimental). Rancangan penelitian ini menggunakan non-equivalent control group desain. Analisis data dalam penelitian ini menggunakan one way anova dengan bantuan SPSS 24.0. Hasil Penelitian ini menunjukkan nilai F-hitung 35.746 dan P-value $(0.000$ $<0.05)$ yang berarti terdapat perbedaan signifikan kemampuan pemecahan masalah geografi antara kelas kontrol dan kelas eksperimen. Skor pemecahan masalah siswa yang menggunakan model project based learning lebih baik dari skor pemecahan masalah siswa yang menggunakan model konvensional. Hal ini disebabkan karena sintak dalam model PjBL mendukung aktivitas pemecahan masalah pada pembelajaran Geografi.
\end{abstract}

Proses pembelajaran di sekolah masih mengalami beberapa permasalahan. Salah satu permasalahan di lapangan adalah mengenai kemampuan pemecahan masalah geografi. Permasalahan ini harus segera diatasi karena kemampuan pemecahan masalah yang rendah akan berpengaruh terhadap kualitas pembelajaran. Jika kemampuan pemecahan masalah Geografi siswa rendah ada indikasi proses pembelajaran geografi di sekolah belum berhasil. Keterampilan memecahkan masalah merupakan keterampilan high older thinking yang penting dikembangkan dalam pembelajaran Geografi. Kemampuan pemecahan perlu diajarkan dan dipelajari siswa ketika belajar geografi. Kemampuan pemecahan masalah menggunakan fungsi berpikir intelektual paling kompleks. Kemampuan pemecahan masalah mengharuskan peserta didik memfungsikan keterampilan berpikir dan menalar (thinking and reasoning skill) dalam proses belajar (Zahroh, Mufti, \& Parno, 2018). Karakteristik materi Geografi di SMA yang banyak mengangkat permasalahan-permasalahan kontekstual di lingkungan siswa dapat melatih keterampilan berpikir dan menalar siswa. Keterampilan berpikir kompleks dan menalar menjadi bekal berharga siswa dalam melakukan aktivitas pemecahan masalah.

Kapasitas peserta didik dalam berpikir secara kritis menjadi modal awal untuk melakukan aktivitas pemecahan masalah. Kemampuan seseorang dalam memutuskan suatu kebenaran maupun kesalahan pada fenomena tertentu dan mencoba untuk memperbaikinya didefinisikan sebagai berpikir kritis (Nurrohmi, Utaya, \& Utomo, 2017). Kompetensi peserta didik untuk melakukan aktivitas perumusan permasalahan, turut aktif dalam penyampaian argument, dapat menganalisis argument, terampil dalam aktivitas pengamatan, berpikir secara induksi deduksi dan memiliki keberanian dalam pengambilan keputusan untuk bertindak merupakan syarat yang harus dipenuhi peserta didik agar dapat dikategorikan memiliki pemikiran kritis (Herzon, Utomo, \& Budijanto, 2018). Kemampuan berpikir kritis siswa pada saat belajar Geografi sangat berguna dalam aktivitas pemecahan masalah. 
SMAN 2 Bae merupakan sekolah yang berada di Kabupaten Kudus yang masih mengalami problematika yaitu rendahnya kemampuan pemecahan masalah. Hasil observasi dan wawancara guru di SMAN 2 Bae menunjukkan beberapa persoalan terkait rendahnya kapasitas peserta didik dalam menyelesaikan permasalahan. Pembelajaran yang dilakukan guru belum mendukung peserta didik untuk berpikir tingkat tinggi mengakibatkan capaian keterampilan memecahkan masalah peserta didik rendah. Rendahnya kemampuan pemecahan masalah pada siswa dapat diamati dengan melihat intensitas siswa mengemukakan ide dan solusi dari sebuah permasalahan (Nurhadi, Utaya, \& Handoyo, 2018).

Hasil observasi kemampuan pemecahan masalah siswa SMAN 2 Bae masih belum optimal. Belum optimalnya kemampuan pemecahan masalah siswa disebabkan proses pembelajaran yang masih terfokus kepada guru. siswa belum terlihat menggunakan pengetahuannya dalam mengkaji dan menganalisis suatu permasalahan. Aktivitas pengumpulan data kontekstual juga masih minim dalam kegiatan pembelajaran sehingga siswa belum terlatih untuk menganalisis suatu permasalahan. Mengajarkan kemampuan pemecahan masalah pada siswa merupakan suatu keharusan. Proses pemecahan masalah menuntut siswa untuk mampu memahami konsep, menerapkan dan mengidentifikasi konsep yang telah dipelajari pada situasi baru (Rafiah, dkk, 2018; Nurhadi, Utaya, \& Handoyo, 2018). Kemampuan pemecahan masalah siswa perlu terus dikembangkan agar siswa dapat mengaplikasikan pengetahuan dalam aktivitas pemecahan masalah.

Pembelajaran yang mengaplikasi model belajar secara tepat dapat menumbuhkan kemampuan pemecahan masalah Geografi siswa. Pembelajaran berbasis proyek yakni bentuk pembelajaran yang memberikan ruang peserta didik dalam aktivitas problem solving dan membuat sebuah karya untuk menjawab permasalahan kontekstual. (Makrufi, Hidayat, \& Muhardjito, 2018). Pada pembelajaran berbasis proyek (PjBL) siswa secara nyata melakukan riset pada objek permasalahan kontekstual dilingkungannya sehingga memberikan ruang berpikir yang lebih kompleks. Aktivitas siswa dalam pembelajaran project yang berupa riset dan pembuatan produk diharapkan mampu menjadi solusi untuk memperbaiki ketidakmampuan siswa dalam memecahkan masalah.

Objek kontekstual yang dapat diangkat sebagai sumber belajar siswa merupakan fokus pembelajaran berbasis proyek $(\mathrm{PjBL})$. Aktivitas menemukan sendiri suatu informasi melalui kegiatan belajar kemudian memvalidasi informasi yang diterima dengan informasi yang sudah ada dapat didefinisikan sebagai pembelajaran kontekstual (Utami, Sumarmi, Utaya, \& Ruja, 2016). Permasalahan kontekstual dapat diwujudkan pada pembelajaran berbasis proyek (PjBL). Aktivitas memecahkan masalah pada pembelajaran berbasis proyek (PjBL) akan semakin bermakna apabila kasus yang diangkat berupa fenomena kontekstual.

Materi geografi memerlukan sebuah inovasi model pembelajaran agar siswa terlatih dalam pemecahan masalah. Salah satu materi yang memerlukan inovasi model pembelajaran adalah kompetensi dasar 3.5 Menganalisis dinamika kependudukan di Indonesia untuk perencanaan pembangunan. Fenomena kependudukan di Indonesia memiliki beberapa permasalahan yang dapat dijadikan kajian kasus yang sangat menarik untuk dibahas pada pembelajaran berbasis proyek (PjBL). Permasalahan kependudukan yang dapat dijadikan tema kasus dalam proyek siswa antara lain tidak meratanya distribusi penduduk, fertilitas, mortalitas dan tingginya angkatan kerja yang tak sebanding dengan lapangan kerja. Hasil pemikiran kritis terhadap suatu permasalahan kemudian dapat dituangkan ke dalam bentuk uji produk.

\section{METODE}

Penelitian ini merupakan tipe penelitan eksperimen semu atau quasi eksperimental. Rancangan eksperimen pada penelitian ini yakni tipe eksperimen dengan grup kontrol yang setara (non-equivalent control group desain). Peneliti memilih dua kelas yakni kelas XI IPS 4 sebagai kelas uji coba model (eksperimen) dan kelas XI IPS 5 sebagai kelompok pengontrol yang menggunakan model konvensional. Teknik penghimpunan data penelitian memakai tes kemampuan memecahkan masalah Geografi. Soal tes terdiri dari enam butir yang disesuaikan dengan indikator memecahkan masalah yakni mengidentifikasi permasalahan, merumuskan permasalahan, menganalisis permasalahan, membuat kesimpulan, melaksanakan evaluasi dan memecahkan serta menyelesaikan masalah. Uji prasyarat pada penelitian ini terdiri dari; uji normalitas, uji homogenitas, dan uji hipotesis. Hipotesis penelitian diperoleh dari hasil analisis menggunakan teknik analisis statistik One-way Analysis of Variance.

\section{HASIL}

Uji prasyarat parametrik yang terdiri dari uji homogenitas dan uji normalitas dilakukan peneliti sebelum uji anova. Hasil uji normalitas dan homogenitas telah terpenuhi kemudian dilanjutkan uji anova satu jalur. Penelitian memiliki tujuan melihat adanya perbedaan antara siswa yang menggunakan pembelajaran PjBL dengan siswa yang menggunakan pembelajaran konvensional terhadap kemampuan pemecahan masalah. Pada tabel 1 disajikan deskripsi hasil analisis kemampuan pemecahan masalah Geografi.

Hasil uji anova membutuhkan langkah awal yang harus terpenuhi yakni uji data normalitas dan uji data homogenitas. Ketika hasil uji data normalitas dan uji data homogenitas terpenuhi maka uji analisis anova satu jalur dapat dilanjutkan. Penelitian ini memiliki tujuan untuk mengetahui kemampuan menyelesaikan masalah siswa yang belajar menggunakan pembelajaran PjBL dan siswa yang belajar menggunakan model belajar konvensional. Pada tabel 1 disajikan perbandingan hasil aktivitas memecahkan masalah siswa. 
Tabel 1. Deskripsi Hasil Analisis Skor Kemampuan Pemecahan Masalah

\begin{tabular}{lccc}
\hline \multicolumn{1}{c}{ Kelas } & Pretest & Postest & Gainscore \\
\hline Eksperimen & 53,89 & 72,74 & 18,85 \\
Kontrol & 56,73 & 68,36 & 11,63 \\
\hline
\end{tabular}

Tabel 1 menggambarkan adanya perbedaan hasil skor pemecahan masalah siswa antara kelas uji coba (eksperimen) dan kelas kontrol. Perbedaan hasil perolehan siswa disebabkan adanya perbedaan perlakuan dikedua kelas. Kelas uji coba (eksperimen) memakai pembelajaran berbasis proyek (PjBL), sedangkan kelas kontrol memakai pembelajaran konvensional. Rata-rata skor pretest kelas eksperimen 53.89, sedangkan rata-rata kelas kontrol 56.73. Selisih skor pretest antara kelas eksperimen dan kelas kontrol sebesar 2.84. Kelas eksperimen dan kelas kontrol mengalami peningkatan kemampuan pemecahan masalah ketika dilakukan posttest. Rata-rata skor kelas eksperimen 72.74 , sedangkan rata-rata skor kelas kontrol 68.36. Kelas eksperimen yang memakai pembelajaran berbasis proyek (PjBL) memperoleh skor pemecahan masalah yang lebih baik dari kelas kontrol ketika dilakukan postest. Selisih skor pemecahan masalah antara kelas eksperimen dan kelas kontrol sebesar 4.38. Rata-rata gain score kelas eksperimen lebih unggul dari kelas kontrol. Gain score pada kelas eksperimen sebesar 18.85, sedangkan kelas kontrol 11.63. Selisih gain score diantara kedua kelas sebesar 7.22.

Tabel 2. Hasil Analisis One Way Anova

Tests of Beetwen-Subjects Effects

\begin{tabular}{llllll}
\hline Source & Type III Sum of Square & Df & Mean Square & F & Sig. \\
\hline Corrected Model & $8477.119^{\mathrm{a}}$ & 3 & 285.706 & 35.746 & .000 \\
Intercept & 538117.021 & 1 & 538117.021 & $6.807 \mathrm{E} 3$ & .000 \\
Model Pembelajaran & 8477.119 & 3 & 2825.706 & 35.746 & .000 \\
Error & 10434.410 & 132 & 79.049 & & \\
Total & 557688.000 & 136 & & & \\
Corrected Total & 18911.529 & 135 & & & \\
\hline
\end{tabular}

Tabel 2 menunjukkan adanya signifikansi pembelajaran berbasis proyek (PjBL) terhadap kemampuan memecahkan masalah geografi. Berdasarkan tabel 2 nilai signifikansi model pembelajaran $0,000<0,05$ yang memiliki arti hipotesis $\mathrm{H} 0$ ditolak. Tabel signifikansi mengindikasikan adanya perbedaan kapasitas siswa dalam aktivitas pemecahan masalah geografi antara siswa yang belajar menggunakan pembelajaran berbasis proyek dan model konvensional. Pembelajaran berbasis proyek ternyata efektif untuk menumbuhkan kemampuan problem solving skills siswa.

\section{PEMBAHASAN}

Berdasarkan hasil penelitian skor pemecahan masalah di kelas eksperimen lebih baik dari kelas kontrol. Hal ini disebakan karena model project based learning memiliki karakteristik yang mendukung aktivitas siswa dalam pemecahan masalah. Pembelajaran berbasis proyek (PjBL) menggunakan kasus/permasalahan sebagai langkah awal untuk mengintegrasikan pengetahuan baru dan aktivitas nyata peserta didik (Grant, 2005). Belajar dalam konteks menyelesaikan proyek dapat melatih kemampuan siswa meningkatkan sistem dan domain pengetahuan yang nantinya dapat berkembang menjadi multiple intelligences (Sumarmi, 2012). Permasalahan kependudukan yang ada di Indonesia bersifat original dan tidak dibuat-buat oleh peneliti sehingga siswa dapat mencari data secara langsung. Aktivitas siswa dalam pengumpulan data dan pengerjaan project mampu meningkatkan kemampuan pemecahan masalah siswa.

Pembelajaran berbasis proyek (PjBL) terbukti mampu mengembangkan kemampuan berpikir siswa. Penelitian relevan tentang pembelajaran berbasis proyek (PjBL) membuktikan bahwa pembelajaran ini mampu meningkatkan kemampuan berpikir kritis (Sularmi, Utomo, \& Ruja, 2018), kemampuan berpikir kreatif (Insyasiska, Zubaidah, \& Susilo, 2015), kemampuan berpikir spasial (Oktavianto, Sumarmi, \& Handoyo, 2017), keterampilan proses sains (Maghfiroh, Susilo, \& Gofur, 2016). Kajian penelitian relevan membuktikan secara empiris bahwa pembelajaran berbasis proyek berdampak positif terhadap kemampuan berpikir siswa. Salah satu kemampuan berpikir siswa yaitu kemampuan pemecahan masalah.

Guru perlu memulai pembelajaran dengan mengkaji permasalahan dengan tujuan mengintegrasikan pengetahuan awal siswa. Pembelajaran yang mengangkat permasalahan kontekstual dapat meningkatkan kemampuan siswa dalam aktivitas pemecahan masalah (Woa, Utaya, \& Susilo, 2018). Project based learning yang diterapkan pada lingkungan belajar, dapat memberikan pengalaman yang bermakna dan meningkatkan problem solving ability (Makrufi, Hidayat, \& Muhardjito, 2018). Pembelajaran berbasis project dengan mengangkat sebuah permasalahan kontekstual terbukti mampu melatih siswa untuk, (1) mengidentifikasi permasalahan, (2) merumuskan permasalahan, (3) menganalisis masalah, (4) membuat kesimpulan, dan (5) membuat solusi pemecahan masalah. 
Keterampilan pemecahan masalah siswa terbangun dengan baik karena adanya dukungan aktivitas yang bersifat kontruktif pada pembelajaran. Pembelajaran berbasis proyek (PjBL) memiliki prosedur pembelajaran yang bersifat konstruktif sehingga mampu memfasilitasi siswa agar dapat belajar secara mandiri (Nurhadi, Utaya, \& Handoyo, 2018). pembelajaran student centered merupakan ciri khas dari pembelajaran berbasis proyek ( $P j B L)$ siswa secara aktif terlibat langsung pada aktivitas investigasi sehingga mampu memahami persoalan kontekstual secara mendalam (Fajarwati, Susilo, \& Indriwati, 2017). Pembelajaran ini mampu menumbuhkan keterampilan menyelesaikan masalah siswa karena siswa terlibat aktif dalam proses investigasi masalah secara mendalam (Hayati, Utaya, \& Astina, 2016). Kemandirian siswa dalam belajar dan keterlibatan siswa secara langsung dalam melakukan investigasi masalah menjadi faktor penting yang berpengaruh terhadap kemampuan pemecahan masalah geografi siswa.

Kompetensi dasar 3.5 menganalisis dinamika kependudukan di Indonesia sesuai karakteristik model project based learning. Pembelajaran project based learning selalu mengangkat permasalahan sebagai starting point dalam pembelajaran (Grant, 2005). Permasalahan pada materi dinamika kependudukan sangat kompleks dan sesuai dengan karakteristik model project based learning. Masalah-masalah kependudukan penting untuk dikaji. Menurut Lestari (2016) manfaat mengkaji permasalahan kependudukan bagi peserta didik dalam pembelajaran geografi, yaitu (1) memberikan penjelasan tentang masalah-masalah geografi yang diakibatkan antara faktor penduduk dengan sumber daya lingkungan, (2) membuka kesadaran peserta didik terhadap berbagai masalah sosial ataupun masalah geografi berupa kemiskinan, kelahiran yang tinggi, pernikahan dini, lonjakan populasi lansia, dan pertumbuhan penduduk yang besar, (3) membuka citra, penghayatan, dan kesadaran peserta didik terhadap permasalahan kependudukan yang terjadi di Indonesia. Masalah-masalah kependudukan yang telah dibahas diatas dapat dijadikan sebagai tugas project siswa.

Tugas project berupa pembuatan majalah dinding kependudukan memuat aktivitas pemecahan masalah. Aktivitas pemecahan masalah membutuhkan sebuah penyelesaian dan pemikiran (decision making) yang dapat dijadikan sebagai solusi terbaik dari sejumlah alternatif jawaban yang tersedia (Maliki, Hidayat, \& Sutopo, 2017). Pembuatan majalah dinding kependudukan berisikan permasalahan kependudukan yang memungkinkan siswa melakukan aktivitas pemecahan masalah. Kegiatan pemecahan masalah yang dilakukan siswa yaitu mencari alternatif jawaban terbaik yang dapat menjadi solusi dari sebuah persoalan.

Langkah-langkah pemecahan masalah dalam pembuatan majalah dinding kependudukan menjadi syarat penyelesaian project. Peneliti mensyaratkan siswa agar melakukan langkah-langkah pemecahan masalah dalam aktivitas penyelesaian project. Indikator pemecahan masalah yang perlu dicantumkan dalam majalah dinding, antara lain (1) identifikasi masalah, (2) merumuskan masalah, (3) menganalisis masalah, (4) menarik kesimpulan, (5) melakukan evaluasi, (6) memecahkan dan menyelesaikan masalah (Nurhadi, 2004); (Crebert et al., 2011). Aktivitas pemecahan masalah yang mendukung aktivitas siswa dalam belajar secara kompleks menjadi salah satu faktor kemampuan pemecahan masalah siswa di kelas eksperimen lebih baik.

\section{SIMPULAN}

Dari hasil kajian pada pembahasan dapat disimpulkan bahwa pembelajaran berbasis proyek (PjBL) memiliki manfaat yang bermakna bagi keterampilan memecahkan masalah siswa. Manfaat yang terbangun melalui aktivitas pembelajaran proyek yakni pemikiran kritis, kreatif, keterampilan spasial yang berguna bagi siswa untuk melakukan aktivitas penyelesaian permasalahan. Keefektifan pembelajaran berbasis proyek (PjBL) dibuktikan dengan perbedaan rata-rata skor antara kelompok eksperimen yang memakai pembelajaran proyek dan kelompok kontrol yang belajar memakai pembelajaran konvensional.

\section{DAFTAR RUJUKAN}

Crebert, G., Patrick, C., Cragnolini, V., Smith, C., Worsfold, K., \& Webb, F. (2011). Problem Solving Skills Toolkit 2nd Edition. Quessland: Griffith University Press.

Fajarwati, S. K., Susilo, H., \& Indriwati, S. E. (2017). Pengaruh Project Based Learning Berbantuan Multimedia terhadap Keterampilan Memecahkan Masalah dan Hasil Belajar Psikomotor Siswa Kelas XI SMA. Jurnal Pendidikan: Teori, Penelitian, dan Pengembangan, 2(3), 315-321.

Grant, M. (2005). Project-Based Learning In a Middle School: Tracing Abilities Through The Artifacts of Learning. Journal of Research on Technology in Education, 38(1), 34.

Hayati, W., Utaya, S., \& Astina, I. K. (2016). Efektivitas Student Worksheet Berbasis Project Based Learning dalam Menumbuhkan Kemampuan Berpikir Kritis Siswa pada Mata Pelajaran Geografi. Jurnal Pendidikan: Teori, Penelitian, dan Pengembangan, 1(3), 468-474.

Herzon, H., Utomo, D., \& Budijanto. (2018). Pengaruh Problem-Based Learning (PBL) terhadap Keterampilan Berpikir Kritis. Jurnal Pendidikan: Teori, Penelitian, dan Pengembangan, 3(1), 42-46.

Insyasiska, D., Zubaidah, S., \& Susilo, H. (2015). Pengaruh Project Based Learning terhadap Motivasi Belajar, Kreativitas, Kemampuan Berpikir Kritis, dan Kemampuan Kognitif Siswa pada Pembelajaran Biologi. Jurnal Pendidikan Biologi, 7(1), 9-21. 
Lestari, T. (2016). Model Prolem Based Learning terhadap Kemampuan Memecahkan Masalah. Jurnal Geografi Gea, 15(1), 17-23. https://doi.org/10.17509/gea.v15i1.4181

Maghfiroh, N., Susilo, H., \& Gofur, A. (2016). Pengaruh Project Based Learning Terhadap Keterampilan Proses Sains Siswa Kelas X SMA Negeri Sidoarjo. Jurnal Pendidikan: Teori, Penelitian, dan Pengembangan, 1(8), 1588-1593.

Makrufi, A., Hidayat, A., \& Muhardjito. (2018). Pengaruh Model Pembelajaran Berbasis Proyek terhadap Kemampuan Pemecahan Masalah Pokok Bahasan Fluida Dinamis. Jurnal Pendidikan: Teori, Penelitian, dan Pengembangan, 3(7), $878-881$.

Maliki, I. M., Hidayat, A., \& Sutopo. (2017). Kemampuan Pemecahan Masalah Siswa pada Topik Suhu dan Kalor melalui Pembelajaran Cognitive Apprenticeship. Jurnal Pendidikan: Teori, Penelitian, dan Pengembangan, 2(2), $304-308$.

Nurhadi. (2004). Pembelajaran Kontekstual dan Penerapannya dalam KBK. Malang: UM Press.

Nurhadi, A., Utaya, S., \& Handoyo, B. (2018). Pengaruh Model Project Based Learning dan Gaya Berpikir terhadap Kemampuan Memecahkan Masalah Mahasiswa Geografi. Jurnal Pendidikan: Teori, Penelitian, dan Pengembangan, 3(7), 974-979.

Nurrohmi, Y., Utaya, S., \& Utomo, D.H. (2017). Pengaruh Model Pembelajaran Discovery Learning terhadap Kemampuan Berpikir Kritis Mahasiswa. Jurnal Pendidikan: Teori, Penelitian, dan Pengembangan, 2(10), 1308-1314.

Oktavianto, A., Sumarmi, \& Handoyo, B. (2017). Pengaruh Project Based Learning dan Gaya Belajar terhadap Kemampuan Berpikir Spasial. Universitas Negeri Malang, Malang.

Sularmi, Utomo, D. H., \& Ruja, I. (2018). Pengaruh Project-Based Learning terhadap Kemampuan Berpikir Kritis. Jurnal Pendidikan: Teori, Penelitian, dan Pengembangan, 3(4), 475-479.

Sumarmi. (2012). Model-Model Pembelajaran Geografi. Malang: Aditya Media.

Utami, W., Sumarmi., Utaya, S., \& Ruja, I. N. (2016). React (Relating, Experiencing, Applying, Cooperative, Transferring) Strategy to Develop Geography Skills. Journal of Education and Practice, 7(17), 2222-1735.

Woa, K., Utaya, S., \& Susilo, S. (2018). Pengaruh Model Pembelajaran Problem Based Learning1400 terhadap Kemampuan Memecahkan Masalah Geografi pada Siswa SMA. Jurnal Pendidikan: Teori, Penelitian, dan Pengembangan, 3(3), 406411. D

Zahroh, S., Mufti, N., \& Parno. (2018). Keterampilan Pemecahan Masalah dengan Model Search, Solve, Create, and Share (SSCS) Problem Solving disertai Conceptual Problem Solving (CPS) pada Materi Hukum Newton. Jurnal Pendidikan: Teori, Penelitian, dan Pengembangan, 3(7), 968-973. 